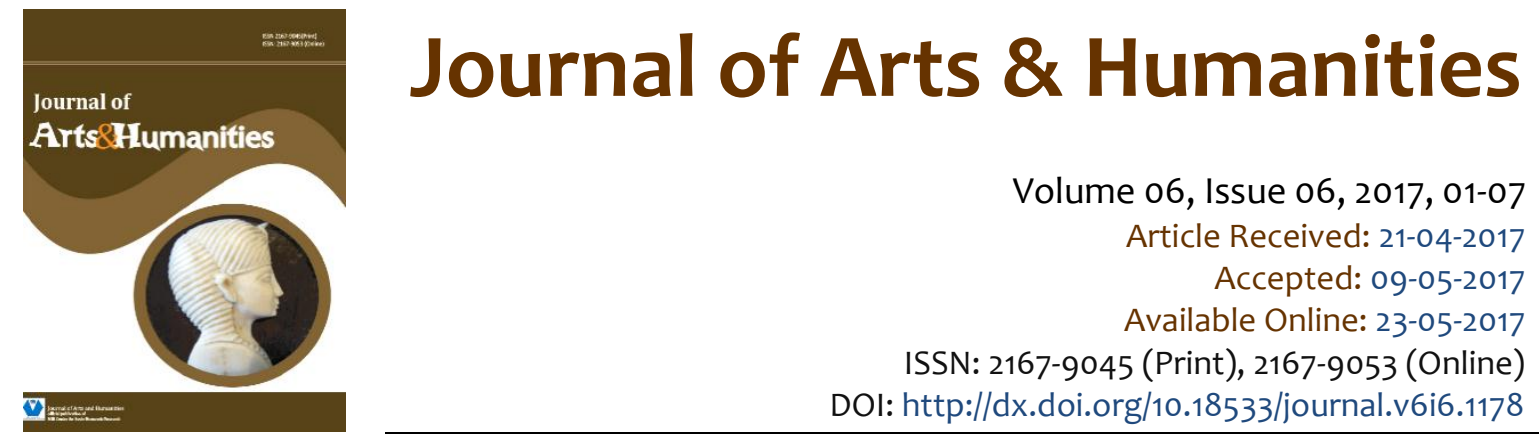

\title{
Seepage Diglossia Pakpak Dairi Language: Sociolinguistics Study
}

\author{
Ida Basaria'
}

\begin{abstract}
Diglossia is essentially a term used to describe a state of the people who know and use two or more languages to communicate among its members (a society that recognized two or more languages for intrasocietal communication). So the use of bilingual diglossia situation or more in the same community 'governed' by a policy for the selection of the language to be use. Event diglossia shows the distribution function of two or more languages are also giving the impression of their kind of language that is "high" and the type of language that is "low", This type of language used is high in situations that are considered more formal, by people including educated, and more prestige value and prestige. While the types of lower language used in situations that are more informal, by the common man and as a means of general intercommunication. In fact, diglossia situation is actually happening in Indonesia; Functions performed by Indonesian high and low functions carried out by the regional languages in Indonesia. National language as a second language that calls for all levels of society to use it, could result in local languages as a first language gradually eroded. If it is forced through, then the language area that is less powerful because it's a little bit unknown can disappear even more in the future. This is certainly very unfortunate, because it coincides with the loss of local languages, indigenous or traditional knowledge stored in the oral tradition also can not be saved. It was when seen from the side of the opposition; Different when seen from the side of the union, then between the local language and national languages can co-exist in harmony. This study wanted to examine the analytic theory of how language Pakpak Dairi sociolinguistic as local and Indonesian language as the national language used by speakers in North Sumatra that suffered disproportionately situation.
\end{abstract}

Keywords: Bilingual, Language Scrape, Seepage Diglossia, Sociolinguistics.

This is an open access article under Creative Commons Attribution 4.0 License.

\section{Introduction}

Indonesian society is a pluralistic society that are multilingual but also single. Singular-plural existence is reflected, among other things, in the diversity of languages used population. The diversity of languages

\footnotetext{
1 Department of Literature, Faculty of Humanities, Universitas Sumatera Utara, North Sumatera, Indonesia. Phone +62618215956, Email : ida1@usu.ac.id
} 
spoken by its inhabitants factions may reflect the ethnic diversity but can not. Ethnicity, according Edwars (1977), Seara identity can be considered a racial group or religion. However, according to Barth (1969 nature Suparla 1995: 2) ethnic group is a social category that is ascriptive in the sense that someone is grouped into a single ethnic group identity based on the most common basis according to its origin and his background. Wherever the opinion that will be used, seems to be a fact on the ground is not necessarily acceptable.

On the bilingual society (dwilingual) such as in Indonesia, will be able to 'sort milahkan' attitude and the use of a second or more languages are used. They will not wear in vain languages mastered. They can find out when and under what circumstances one language is used, and when and under what circumstances also other languages used. Thus the development of the language that will be directed and balanced.

National language as a second language that calls for all levels of society to use it, could result in local languages as a first language sedikti gradually eroded. If it is forced through, then the local language a little less robust alias users can disappear even completely unknown in the future. I could have formed so-called pattern substractive bilingual in Indonesian society, namely the mastery of a second language (Indonesian) gradually replaced the first language (vernacular) (Hidayat 2006: 39). This is certainly very unfortunate, because it coincides with the loss of local languages, indigenous or traditional knowledge stored in the oral tradition also can not be saved. It was when seen from the side of the opposition; Different when seen from the side of the union, then between the local language and national languages can co-exist in harmony. In addition to the schools taught Indonesian, also still taught in their native language (vernacular). If it so happens, there will be no mutual removal of one another. National language does not remove the local language, and vice versa. It thus had no indication from the government, with the issuance of the policy line that had been developed in the framework of the promotion and development of regional languages, namely as follows: "Languages area that is still used as a means of transportation that is alive and nurtured by the community pemaikainya, appreciated and maintained by the state because these languages are part of the culture of life

This article will discuss the presence of Pakpak Dairi Language (hereinafter abbreviated BPD) used in North Sumatra, precisely in Dairi regency Sidikalang which will be highlighted through studies, especially concerning the latest sosiolinguitik language shift maintenane language and language shift from the existing sociolinguistic literature. In fact BPD showed indications have experienced ketergeseran use by speakers-speakers are turning to Indonesian or even language Batak Toba.

\section{Literature}

\section{$2.1 \quad$ Dwi lingual}

Events of using two or more languages in a pluralistic society, according to Grosjean (1982), is a natural phenomenon. According to him, children tend to establish themselves as bilingual or even multibahasawan naturally without planned by their parents. Berasarkan forecast Holmes (1992: 79) and Grosjean (in Romain, 1989: vii) almost half of the world's population is bilingual and bilingualism or bilingualitas found in almost every country in the world. In fact, according to Romain, community kebahasawan (monolingual) is not a homogeneous society, therefore the presence of social and regional diversity of styles in a so-called 'one language'. It can be encountered everywhere, not least in the areas in Indonesia. In a pluralistic society one language is the language of the ethnic group, the other one is used in the wider environment outside the tribe, for example in the market, and another for communication purposes in school or in the office. In sosilinguistik linguistic situation like this is called poliglosia. (See Wilian 2002; 92)

Holmes pointed a teenager in the town of Bukavu, Zaire, named Kalla ( 16 th), who speaks several languages for communication purposes are different. At home with his family he was speaking Shi, ethnic language. If you want to communicate with someone from another tribe, he uses language 
Kingwana lingua franca, the language of the non-standard market Swahili. Later at school he learned to speak Swahili standards, which is one naisonal language, alongside French. When playing with their peers on the streets, using language Indoubil Kalla, a hodgepodge of language variation (a mixture of Swahili, French, English and Italian) used between groups of young people in the city of Bukavu. (See Wilian, 2002: 93)

Part of the community for Indonesia, especially in rural areas, the situation is approximately the same as experienced Kalla in Zaire, Africa, the above are found. No exception for people in Sidikalang Pakpak Dairi. It seems that, sooner or later bilingualism unstable, negative attitudes toward their own local language or mother tongue, the occurrence of intermarriage, migration of the population will lead to competition and a shift in language that was great everywhere. It is based on the fact, which can inferented of several studies, that among the younger generation in the region tends to use the Indonesian language or languages other than their mother tongue area.

\subsection{Diglossia}

Diglossia is essentially a term used to describe a state of the people who know and use two or more languages to communicate among its members (a society that Recognized two or more languages for introsocietal communication). (See Fisman (1975; Wolff 1974). So the situation of diglossia use of two or more languages in the same community 'governed' by a policy for the selection of the language to be used. Diglossia events indicates the division of language function also gives the impression that there kind of language that "high" and the type of language that is "low". This type of language used is high in situations that are considered more formal, by people including educated, and more prestige value and prestige. While the types of lower language used in situations that are more informal, by the common man and as a means of public association.

So in fact, this diglossia situation actually occurred in Indonesia. In seepage diglossia situation, in national policy, Indonesian corresponding position serves as a communication tool or national state; regional language serves to intra ethnics communication tool; While foreign language serves as a means of communication between peoples and adder science.

\subsection{Seepage diglossia}

As mentioned above, bilingualism itself does not cause any of the languages that there be pressed; their two languages do not necessarily lead to the two languages are "competing" or "scramble to wear." Competition was incurred for members of the community began to apply serious benefits cost analysis (cost benefit analysis) on the use and learning of languages. They weigh what maculate obtained and how much it costs to be paid if they choose to use (and learn) the language that one instead of the other language. From this emergence of the possibility that the language used to get preference for the citizens instead of another language. In other words, languages that do not get preference, the (starting) compete and keep pressed. The language was not just pushed into the realm of home or family sphere. However, if the dominant language persisted and this occurs when the leaklanguage diplopia compete it continues shifted, squeezed and eventually dying. If people leave it alone. Ultimately inevitable dying language will die.

The term diglossia refers to the language situation in which each language or language variety, both in the public monolingual (monolingual), bilingual (bilingual), or multilingual, has the role and function of each varying according allotment (Ferguson, 1959). Division or separation of the functions normally associated with what is termed a variety of language T (High) and a variety of language R (Low). T language diversity is associated with language or variety of language that is appreciated and recognized in the community has a high value (highly valued), while the variety of language $R$ appreciated having a lower value (less valued). Domains use informal language like family, neighbors, and intimacy is considered to be the realm where $\mathrm{R}$ language is used, whereas the realm of religion, 
education, government, and the working environment is considered the realm of formal language use (this includes language region $\mathrm{T}$ ).

In a society that every language has its own function which is used by members to declare his will according to social norms language communities concerned. Use of each language or language variety that is determined by the behavior, attitudes, and values that exist in the society regarding any language or variety of language used. The different attitudes and views of every language is due to the fact that in a monolingual society or language variety is considered to have 'limited' (in the sense of having the function) individually. To watch in the use and choice of language associated with the concept of diglossia that is that if the domains of language usage that had been represented by a variety of language $R$ already entered or is replaced by a variety of language $T$ (diglossia leakage) then the suspect will start a shift in the language.

\section{Methodology}

This study population are members of ethnic communities living in BPD research site located in the district town Sidikalang, aged $<10$ years to 60 years. The main data was obtained from respondents obtained through a questionnaire survey, in addition to data from ethnographic methods with participant observation and interview techniques.

The survey questionnaire contains a list of questions inducement recognition of self (self-report) on the use and selection of respondents as used Gunarwan language to language Lampung (1994) and Wilian which examines language Sasak in Lombok (2010). Questionnaires distributed randomly to the study site by taking into account the distribution of each dialect. Then to complete the crawl data through a survey method, the researchers were also speakers BPD and assisted several research assistants will make observations involved incorporating participatory observation sheet or recording sheet (Muda et al., 2016). Then the data in the analysis of this descriptive method with a qualitative approach (Sirojuzilam, et a.l, 2016; Muda et al., 2016 and Tarmizi, et al., 2017). The survey data and observations obtained after selected, inventoried, and clarified, then tabulated to calculate the frequency of occurrence for each variable according their respective groups.

\section{Discussion}

BPD is the language used by the tribe Pakpak Dairi. BPD may be called the Dairi Pakpak Batak language is one of the four languages other Batak be relatives. The fourth language into relatives BPD is language Batak Toba Batak Karo Batak Simalungun and Batak language Angkola Mandailing. The mention of the fifth language often abbreviated course with the language Toba, Karo, Simalungun language, language Angkola and including BPD. Deletion at the mention of the word Batak language (including a reference to his tribe) is only to shorten at the mention of (economic language). The trend appears that the reference to the Batak tribe is now used to refer to the five tribes of the related languages, while the languages Batak term is more appropriate to refer to these five languages. Batak language has evolved into five languages, as mentioned above. Development and separation was an odyssey that run in a reasonable language (see Sibarani, 1997: 2; Basaria, 2011).

Due to the effect of population growth, the expansion of the neighborhood, and the influence of other languages, has had an impact on the development and the separation of languages Batak so that these five languages into different languages because there are communication barriers or almost no longer mutual understanding (mutual intelligibility). So BPD is now developing into a different language with four other Batak language.

Solin (1998: 112) states that the speaker is the speaker multilingualis BPD is BPD and language Batak Toba, on the Indonesian side. According to him, Toba Batak language is widely used/used by speakers Pakpak Christian, which is the majority religion tribes Pakpak Pakpak tribe is due to Dairi.Hal Christian Batak Toba major language in a religious ceremony at the HKBP church, which became the church the 
first is in the area / land Batak (included in Pakpak). In the last few years there is a new stand GKPPD that uses BPD. Further overseas, BPD very rarely used, especially when met with tribes Toba. In addition, there is a tendency attitudes of young public speakers who feel inferior or ashamed considered the unlearned if using BPD They prefer to use Indonesian or regional language Batak Toba any language Karo in daily life, both in its own environment and outside environment.

\subsection{Language and symptoms shift language Pakpak Dairi}

Languages shifting and the 'urgency' is characterized by the presence of speakers of the language which is dominated by the elders and residents bayanya half, reflecting the absence of language switching it to the younger generation. It also identifies any other language is considered more important for the future. Over time, the language will become smaller number of speakers and the basis of its useful area will disappear. Furthermore, according to Edward, bilingualism is often only a symptom of temporal which will be replaced by monolingualisme dominant language. Signs on, it was already there anyway in bilingual BPD as it was also revealed from the recognition I've interviewed informants who say that at home they often also use language Batak Toba or Indonesian with his brothers.

In general, the symptoms of the language shift is also being hit languages other regions in Indonesia, such as language Lampung (Gunarwan 2001). Based on his research, by comparing the strength of the local language and Indonesian according to its concept geolinguistik Mackey (1973), concluded that the symptoms tergesernya Gunarwan vernacular language occurred in Lampung. Then, on the scale of the election implikasional Indonesian or Lampung found that more and more young people of Lampung, the greater the Indonesian kecendrungannya use, instead of Lampung language at home (IBI). Evidence that today in many regions in Indonesia was a shift in the language 'language shift' among the younger generation can be traced from several studies. The results of research by Muhajir, et al (1988) examine the language shift in Mentawai, Wantania (1996) investigated the shift and retention of language Arcartia in North Sulawesi, as well as Gunarwan (2001a) discusses the case of stability bilingualitas Indonesia and Bali among Balinese, everything shows that the languages of the region is an ongoing shift language use, both from the local language into other regional languages as well as into Indonesian.

\subsection{Attitudes language speakers}

The linguists who devote attention to the symptoms of extinction of minority languages, especially languages in developing countries concluded that the main cause of extinction of languages is because parents no longer teach their mother tongue to their children and no longer active use it at home in a variety of communication domains (Grimes 2000: 17). So, it is not because the extinction of native speakers stopped speak, but the consequences of the choice of language use most of the people he said (Landweer 1999: 1). Speakers chose not membelajarkan mother tongue to their children and choose not to use an active way in the realm of substitutions at home. Based on the opinion of Grimes above, this study will examine how the use of BPD in the realm of non-formal at home in the realm of family and neighborhoods.

The family is most important fortress of the survival of regional languages. The family inheritance indeed is the venue for the sustainability of the mother-tongue of parents to their children or from one generation to the next. In other words, that's where berprosesnya, according to the terms Fishman (1993), the sustainability of intergenerational transfer of mother tongue-the "mother-tongue intergenerational continuity". In the realm of family or home tanggalah occur intense communication between mother and father, siblings, parents-children, grandparents, grandchildren, and other family members so that the process of transferring the language of the older generation to the younger generation can run. Usually communication in the household with respect to matters kerumhtanggaan and various other life problems. Here, too, can be seen in the language use patterns of all family members that when they communicate in the house. So long as these families are still willing to use the 
language of her mother in the home as the primary communication tool during the same BPD will still be able to survive.

In the context of this study, which wants to be seen is whether the use of BI on BPD dominance in society Pakpak has caused a shift or retention. Based on the weighting scenarios in which the above mentioned methodology this means that only respondents over the age of 60 who are still always (almost always) using BPD than BI. Judging from the parameters of the age of respondents to answer option (the language used in the realm of the family) it seems that, as shown in Table 1 below.

Table 1: Average propensity choice of language in the realm of the family according to age groups of respondents

\begin{tabular}{lrrr}
\hline No & Age group & N & The average value of Elections \\
\hline 1 & $>60$ & 9 & 1,15 \\
2 & $51-60$ & 18 & 1,21 \\
3 & $41-50$ & 27 & 2,02 \\
4 & $31-40$ & 64 & 2,31 \\
5 & $21-30$ & 84 & 2,69 \\
6 & $\leq 20$ & 34 & 2,78 \\
\hline
\end{tabular}

Sources: Gunarwan (1999)

$(1=$ always $/$ almost always BPD; $2=\mathrm{BPD}>\mathrm{BI} ; 3=\mathrm{BPD}=\mathrm{Bl} ; 4=\mathrm{BI}>\mathrm{BPD} ; 5=$ always $/$ almost always BI $)$. Scalability $=$ $100 \%$

As seen, in the family society Pakpak Dairi observed seepage diglossia in the 41-50 age group (average value election -2.02), implies that the central bank has begun to be used in the realm of home. Concern is the lower age groups Pakpak family of the higher average value of the language selection. This suggests that the younger family Pakpak ethnic Indonesian increasingly being used instead of BPD. So, judging from the age group of respondents, according to the scale of propensity scores language choice at home, it appears that the mean selection of language form the scalability of language options, which means the younger the age group of respondents is relatively greater opportunities to use $\mathrm{BI}$, this implies also that there are likely trends in between young people and married young couples - especially those high educational background and civil servants - to "get used" to use $\mathrm{BI}$ as an everyday language at home, although the difference between the index is still small and not statistically significant as implied, the quantity of use BPD tends to go down, and vice versa quantity BI usage tends to increase according to age parameter. The lower the speakers of the lower age also use BPD. What is interesting is that the use of BPD was positively correlated with attitudes toward the BPD, as shown in Table 1 means the more negative the attitude of respondents to the BPD, diminishing the quantity of use of BPD.

Attitude teen/youth BPD mother tongue speakers, almost all are no longer using the BPD when they meet with their friends in another place/city that uses the same language. They even tend to use language Batak Toba or Indonesian language. But for speakers BPD (age \pm 45 years and above), they usually skip the code / language to BPD if they knew that their interlocutors are ethnic BPD .This indicates that among older speakers, BPD is still used, however there is a phenomenon a shift in language usage by the speakers of BPD in Dairi regency are turning to Indonesian or sometimes switch to Toba Batak language which they consider more prestigious. Speakers of young people consider that Indonesian or Batak Toba language is more prestigious than BPD. Indeed, it is hinted that seepage diglosida has occurred. If allowed, seepage will be even greater, and if left without any attempt to patch seepage BPD can be within the estimated time of 75-100 years, if no effort reversal of BPD. As with any living thing, it seems the language are subject to the laws of natural selection, which evolutionists formulated into a phase of the survival of the fittes, which in essence is that only the most important were able to adjust in the struggle against the natural selection will be sustainable life.

In the literature sociolinguistics, there is never enough popular opinion that language is analogous to the organism and that therefore every language has a life span 'natural' (Edwards, 1985: 48). This 
opinion explains that all languages will die of natural causes, in addition there is a language that died in a murder languages (linguicida). Another opinion, which is now acceptable is that the language does have a certain life span, and it depends on the owner or user. Native society that determines whether the language continues to survive or not. They are the keepers of their language so that he remains healthy and able to withstand the urge. Their loyalty will be the language they are able to assure their language will survive. (Fishman, 1974; see Gunarwan, 2002).

If it is associated with the concept of Fishman recommends whether the bilingualism someone there diglossia, namely the use of two or more languages are completely different with different functions (Fishman 1972b: 75), assuming the Indonesian or Batak Toba as the high variety ( $T$ ) and low varieties BPD (R), the realm of language that low varieties like home and family domains has been entered by the high variety of languages. If this is the case will appear the so-called expert's sociolinguistics as seepage diglossia or leakage. Dairi Pakpak language usage in the realm of home/family actually been entered by the Indonesian or Batak Toba, as reflected in the BPD native speakers and have dislocated inter-generational continuity BPD speakers, it can be ascertained that the BPD will someday be extinct.

\section{Conclusion}

The use of Bahasa Indonesia already seeping in and used in the realm of home among speakers Pakpak Dairi language; means seepage diglossia has occurred in Dairi Pakpak language.

\section{References}

DEPDIKNAS. Linguistic Characteristics 2000. Residents in Sitiung Transmigration of West Sumatra Province: A Study of Sociolinguistics. Jakarta: Development and Language Development Center DEPDIKNAS.

Downes, William. 1984. Languages and soicety. Cambridge: Cambridge University Press.

Edward, John. 1985. Languages, society, and Identity. Oxford: Basil Blackwell.

Frishman, Joshua A. 1972. Readings in the Sociology of Language. The Hague: Mouton.

.............. 1977. Revershing Language Shift. Cleveon: Multilingual Matters

Grimes, Barbara F. 2001. The tendency of language to life or death globally: causes, symptoms, and recovery for languages that are endangered. PELBBA 15 UNIKA ATMA JAYA, Jakarta.

Grosjan, F. 1998. Life with Two Languages. Cambridge, Mass: Harvard University.

Gunarwan, Asim. 1999. Reversal of Lampung Language Shift: Could it be?. Papers on Language and Writing Seminar Lampung. Bandar Lampung, October 23, 1999.

Gunarwan, Asim.2002. Case Shifts Local Language: Due to competition with Indonesian. Journal of Linguistics Indonesia. 24(1). 33-43.

Ibrahim, Ali Ibrahim. 2011. Endangered Language: Facts, Reasons Causes, Symptoms and Treatment Strategies in the journal Linguistics Indonesia. 29(1). 67-78.

Muda, I, Marlon Sihombing, Erni Jumilawati and Abikusno Dharsuky. 2016. Critical Success Factors Downstream Palm Oil Based Small And Medium Enterprises (SME) In Indonesia. International Journal of Economic Research. 13(8), 3531-3538.

Sirojuzilam, Hakim, S., and Muda, I. 2016. Identification of factors of failure of Barisan Mountains Agropolitan area development in North Sumatera-Indonesia. International Journal of Economic Research. 13(5). 2163-2175.

Suwito. 1993. Sociolinguistics Introduction to Early. Surakarta: Offset Henary Solo

Solin, Matsyuhito.1998. In Tradition and Change: Context Peoples Pakpak Dairi. Terrain: Monora.

Tarmizi, HB., Daulay, M., and Muda, I. 2017. Impact of the Economic Growth and Acquisition of Land to the Construction Cost Index in North Sumatera. IOP Conference Series: Materials Science and Engineering. 180. doi: 10.1088/1757-899X/180/1/012004. 